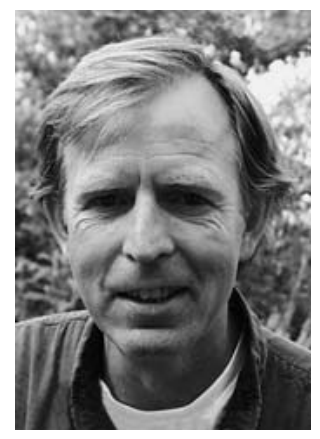

\title{
Over the Edge
}

It was during his holidays ten years back. Someone came running to him and told him to come quickly. Something had happened to his eldest son, who was then seventeen. The father ran back with the boy and saw a group of people around John, who was sitting on the ground. He kept his hand in front of his mouth. Blood was dripping through his fingers. The bystanders told the father what had happened: a group of boys had been throwing water balloons at each other. John had hit one who didn't take it well and started angrily chasing him. In an attempt to escape John had run into an iron mast.

While everyone around was rather upset, John was calm. The father examined him. His lower lip was torn and he was missing eight teeth. Some were loose in his mouth, some were in his hand, some in the grass. People started discussing who to call, and John with his mouth full of blood calmly said, "call 911". He was the only one in control.

The boy who had been chasing him stood nearby with a guilty look on his face. John looked up at him and said "you shouldn't be feeling guilty, for this is not your fault". The father was already impressed by his son's calmness, but now he felt deeply moved by this loving gesture, this sweet nature.

An ambulance brought the two of them to the ferry. Since it was night the crew had been alerted by phone to prepare the boat, and by the time John and his father arrived they were able to drive directly onto the boat and were brought to the shore, from where it was a short ride to the hospital.

The next day they returned to the island. John had been operated on that night and would need several more operations in the future. He was walking on crutches since he had also hurt his knee. Since there was not much he could do besides sitting, the father suggested giving him a flying lesson. On and off he had been talking about learning to fly and on the island there was a small airfield.

When next day John returned on crutches from the airplane there was a big smile on his face. "Now I know what I want!" He had loved it up in the air. He decided he wanted to fly the best plane in the world and enlisted in the Royal Dutch Air Force. After some 20 days of all kinds of tests he was part of the one percent who had passed them all.

By the time you are reading this, John is in Afghanistan. He flew his F16 from the Netherlands to Kandahar, and will fly his missions from there.

Why? Because we live in a world that is continuously going over the edge. Because in situations of chaos people who can stay calm are sorely needed. Because especially in a war a country is better represented by men and women with a loving and forgiving nature. Because he feels that if he can back up a political decision he should also be willing to execute it. But most of all ... because he loves to fly.

While John is on his mission in Afghanistan in the hope helping to restore peace and creating a better life for the Afghan people I am in Africa trying to restore health and create a better life for those living with HIV. He will kill people while I try to save lives. That seems a big difference, but actually we are doing exactly the same thing. We are both fighting reality, because we feel the world should be a different place.

Do you recognize this? That although you are using homeopathy you may tend to fight disease with an allopathic attitude? Homeopathy as I understand it is an expression of love. Giving the simillimum is expressing full acceptance of the state a person is in. The beauty of loving what is, of accepting pain, suffering and death, is that this embracing of reality is what gives space for change. A perfect paradox.

Two years ago, sitting in front of a severely emaciated woman with AIDS, I could feel this. "If you die from AIDS that is absolutely okay with me" is what I realised. She lived, and that was absolutely okay too. Does accepting reality imply we should stop doing what we do? Not for me. I love what I do... just as John loves to fly.

Harry van der Zee, Editor 